\title{
A Standardized Ecosystem Classification for the Coordination and Design of Long-term Terrestrial Ecosystem Monitoring in Arctic-Subarctic Biomes
}

\author{
Donald S. McLennan, ${ }^{1,2}$ William H. MacKenzie, ${ }^{3}$ Del Meidinger, ${ }^{4}$ Johann Wagner ${ }^{1}$ and Christopher Arko ${ }^{1}$
}

(Received 9 January 2017; accepted in revised form 2 February 2018)

\begin{abstract}
A Canadian Arctic-Subarctic Biogeoclimatic Ecosystem Classification (CASBEC) is proposed as a standardized classification approach for Subarctic and Arctic terrestrial ecosystems across Canada and potentially throughout the circumpolar area. The CASBEC is grounded in long-standing terrestrial ecosystem classification theory and builds on concepts developed for ecosystems in British Columbia, Quebec, and Yukon. The fundamental classification unit of the CASBEC, the plant association, is compatible with the lower-level classifications of the Arctic Vegetation Classification (AVC), the Canadian National Vegetation Classification (CNVC), and the United States National Vegetation Classification (USNVC) and is used to generate a classification and nomenclature for Arctic and Subarctic terrestrial ecological communities. The use of a multi-scalar ecosystem framework, such as that developed by the British Columbia Biogeoclimatic Ecosystem Classification, provides an ecological context to use classified plant associations to delineate and define climatically equivalent regional scale climate units (biogeoclimatic subzones) and ecologically equivalent local-scale site units within biogeoclimatic subzones. A standardized framework and taxonomy of ecosystem classification for Subarctic and Arctic terrestrial ecological communities will facilitate the planning, coordination, and applicability of terrestrial ecological monitoring and research. The CASBEC classification and high-resolution ecosystem mapping are being used to develop an effective experimental design, to select ecosite types for long-term monitoring, and to extrapolate results to landscape scales in the Experimental and Reference Area of the Canadian High Arctic Research Station (CHARS) in Cambridge Bay. Widespread adoption of the CASBEC could provide a spatial and functionally scalable framework and a common language for interpreting, integrating, coordinating, and communicating Arctic and Subarctic monitoring, research, and land management activities across the Canadian North and around the circumpolar area.
\end{abstract}

Key words: tundra; terrestrial ecosystem classification; terrestrial ecosystem mapping; vegetation classification; tundra plant community; monitoring; Arctic vegetation; Subarctic vegetation; plant association; zonal concept; ecological site; biogeoclimatic; hypothesis-based monitoring

RÉSUMÉ. Une classification biogéoclimatique arctique et subarctique canadienne (Canadian Arctic-Subarctic Biogeoclimatic Ecosystem Classification, ou CASBEC) est proposée en tant que méthode de classification standardisée pour les écosystèmes terrestres arctiques et subarctiques pancanadiens, et peut-être même pour les écosystèmes de la région circumpolaire. CASBEC s'appuie sur une théorie de classification des écosystèmes terrestres de longue date et sur des concepts mis au point pour les écosystèmes de la Colombie-Britannique, du Québec et du Yukon. L'unité de classification fondamentale de CASBEC, soit l'association végétale, est compatible avec les classifications de niveau inférieur de la classification de la végétation de l'Arctique (Arctic Vegetation Classification, ou AVC), de la Classification nationale de la végétation du Canada (CNVC) et de la classification nationale de la végétation des États-Unis (USNVC). Elle permet de produire une classification et une nomenclature pour les communautés écologiques terrestres arctiques et subarctiques. Le recours à un cadre écosystémique multiscalaire, comme celui élaboré par la classification écosystémique biogéoclimatique de la Colombie-Britannique, fournit un contexte écologique permettant d'utiliser les associations végétales classifiées pour délimiter et définir les unités climatiques régionales à l'échelle climatiquement équivalentes (sous-zones biogéoclimatiques) et les unités écologiquement équivalentes de sites d'envergure locale à l'intérieur des sous-zones biogéoclimatiques. La mise en place d'une taxonomie et d'un cadre standardisés de classification des écosystèmes des communautés écologiques terrestres arctiques et subarctiques facilitera la planification, la coordination et l'applicabilité des travaux de surveillance et de recherche écologique terrestre. La classification CASBEC et la cartographie des écosystèmes en haute résolution sont employées pour mettre au point une conception expérimentale efficace, pour sélectionner des types d'écosites à des fins de surveillance à long terme ainsi que pour extrapoler les résultats à l'échelle des paysages dans la zone d'expérimentation et de référence de la Station canadienne de recherche dans l'Extrême-Arctique (SCREA) à Cambridge Bay. L'adoption de CASBEC à grande échelle pourrait fournir un cadre spatial et fonctionnellement extensible de même qu'un langage commun pour interpréter, intégrer, coordonner et

\footnotetext{
${ }^{1}$ Polar Knowledge Canada, 360 Albert Street, Suite 1710, Ottawa, Ontario K1R 7X7, Canada

${ }^{2}$ Corresponding author: donald.mclennan@polar.gc.ca

${ }^{3}$ British Columbia Ministry of Forests, Lands and Natural Resource Operations, Smithers, British Columbia V0J 2N0, Canada

${ }^{4}$ Meidinger Ecological Consultants Ltd., 639 Vanalman Avenue, Victoria, British Columbia V8Z 3A8, Canada

(C) The Arctic Institute of North America
} 
communiquer les activités de surveillance, de recherche et de gestion des terres arctiques et subarctiques à la grandeur du Nord canadien et de l'ensemble de la région circumpolaire.

Mots clés : toundra; classification de l'écosystème terrestre; cartographie des écosystèmes terrestres; classification végétale; communauté des plantes de la toundra; surveillance; végétation arctique; végétation subarctique; association végétale; concept zonal; site écologique; biogéoclimatique; surveillance fondée sur des hypothèses

Traduit pour la revue Arctic par Nicole Giguère.

\section{INTRODUCTION}

The Canadian Arctic-Subarctic Biogeoclimatic Ecosystem Classification (CASBEC) is an initiative led by science staff of Polar Knowledge Canada's Canadian High Arctic Research Station (CHARS) in Cambridge Bay, Nunavut (McLennan et al., in press). The objective in developing the CASBEC is to develop a standardized approach to classifying, naming, and interpreting Arctic and Subarctic terrestrial ecological communities at a range of scales, to support more coordinated research and monitoring activities across the Canadian North.

Ecosystem units developed through the CASBEC are based on standardized plant association units evolving from developing Canadian Arctic-Subarctic classification initiatives under the Canadian National Vegetation Classification (CNVC, 2015). Led by the Canadian Forest Service, the CNVC involves a partnership of federal, provincial, and territorial vegetation classification practitioners in Canada. Until recently, CNVC work focussed on forest ecosystem classification, but funding provided under the International Polar Year, and more recently by the Yukon Government and Polar Knowledge Canada, has resulted in the development of draft vegetation classifications for both Subarctic and Arctic vegetation communities in the Canadian North (Lévesque et al., 2013; MacKenzie, 2013; MacKenzie and Meidinger, 2018). Arctic and Subarctic work under the CNVC is the Canadian contribution to the circumpolar Arctic Vegetation Archive (AVA) and Arctic Vegetation Classification (AVC), which are initiatives designed to consolidate vegetation data and classifications in member nations around the Arctic (Walker et al., 1994, 2005, 2013, 2018; Walker and Raynolds, 2011; Walker, 2014). Linkage to the international AVA/ AVC provides the opportunity for future development of a correlated ecosystem classification that can coordinate and support circumpolar monitoring and research initiatives.

Using and adapting approaches well developed in southern Canada (Pojar et al, 1987; Ponomarenko and Alvo, 2001), we outline how a standardized classification for Canadian Arctic and Subarctic plant communities is central to the development of a standardized classification of Arctic and Subarctic terrestrial ecosystems, which is at the heart of the CASBEC. We outline the structure of the CASBEC and discuss how the CASBEC can provide an ecosystembased template for designing and coordinating terrestrial monitoring and research objectives across the Canadian North and eventually across the circumpolar regions.

\section{FROM VEGETATION CLASSIFICATION TO TERRESTRIAL ECOSYSTEM CLASSIFICATION}

Terrestrial ecosystem classification has a long history of development, with its roots in Russia and northern Europe, and many variations in southern Canada and the United States. Over the last 25 years, there has been a consistent effort by all Canadian provinces to develop provincial forest ecosystem classifications, many of which are similar in structure and include similar concepts (although different terms) of ecological site, plant community, plant association, and ecological community. Following the pioneering approaches of Hills and Pierpoint (1960) and Krajina (1959, 1965), more modern examples are Meades and Moores (1989) in Newfoundland, Neily et al. (2003) in Nova Scotia, Matson and Power (1996) and Zelazny et al. (1989) in New Brunswick, Bergeron et al. (1992) and Saucier et al. (1998) in Quebec, Lee et al. (1998) and Sims et al. (1989) in Ontario, Zoladeski et al. (1995) in Manitoba, Beckingham et al. (1996a) and McLaughlan et al. (2010) in Saskatchewan, Beckingham et al. (1996b) and Corns and Annas (1986) in Alberta, Pojar et al. (1987) in British Columbia, and more recently, Environment Yukon $(2016,2017)$ for Yukon.

At the heart of all of these classifications is the marriage of the biotic (plant community) and abiotic (ecological site) components of terrestrial landscapes. Krajina (1959) initiated these ideas for ecosystems in British Columbia based on the Russian concept of the biogeocoenose - areas of a landscape that are relatively homogenous in terms of species composition and vegetation structure, in hydrologic, atmospheric and soil conditions, and in the type and matter of energy exchange and interactions among all components (Sukachev, 1960; Sukachev and Dylis, 1968; also adapted from Teplyakov et al., 1998).

The biogeocoenose (Krajina, 1965) can be thought of as a synonym for the more modern term "(terrestrial) ecological community," which we will use here to refer to a particular plant association and its scope of site conditions that are the objects of classification under CASBEC. A terrestrial ecological community includes all of the biota on a site, from soil microbes and invertebrates, through to the plants, pathogens, herbivores, and predators that comprise the local-scale ecosystem. The concept also includes the environmental setting and factors that in part control biotic composition, abundance, and productivity, as well as the interactions among all abiotic and biotic components.

It is impossible of course to observe and record the complex of all ecosystem components and interactions, 
even in relatively simple Arctic and Subarctic terrestrial ecological communities. For practical purposes, terrestrial ecosystems are described and classified using the co-distributions of plant communities as defined by relevé data classified into plant associations (Shimwell, 1971; Ellenberg, 1988) and the scope of site conditions using standardized site and soil description methods (BC Government, 2010) on which they occur. Similar vegetation communities typically repeat themselves in a predictable pattern across the landscape, recurring in similar environmental settings. Boundaries between ecological communities may be abrupt, as at the margin of a wetland or floodplain, or they may change gradually, as along an even slope, where downslope seepage is the driving ecological factor.

\section{CANADIAN ARCTIC-SUBARCTIC BIOGEOCLIMATIC ECOSYSTEM CLASSIFICATION (CASBEC)}

To develop the CASBEC for Subarctic and Arctic ecological communities, we have adopted approaches developed by the Biogeoclimatic Ecosystem Classification (BEC) system of British Columbia (Pojar et al., 1987; Meidinger and Pojar, 1991; MacKenzie and Meidinger, 2018), and more recently by Environment Yukon (2016) in the Yukon. The CASBEC (Fig. 1) is composed of three integrated classifications - a central vegetation classification of plant communities following the BEC and Braun-Blanquet approach, with linkage of the plant associations to ground-based biogeoclimatic and ecological site classifications using the key concepts of "zonal" or "reference" ecosystems and "ecological equivalence," as discussed below.

\section{Vegetation Classification}

The classification of plant communities has a long academic history in Europe (Shimwell, 1971; MuellerDombois and Ellenberg, 1974) and has been broadly applied across North America (Whittaker, 1962, 1973; CNVC, 2015; USNVC, 2016). The CASBEC uses vegetation classification approaches as outlined in MacKenzie and Meidinger (2018) to generate working units, which are linked to standards in the CNVC and USNVC (Jennings et al., 2004, 2009). To generate a classification for an area of study, relevés are collected, with replication, from the range of observed plant communities and sites within an area of study. The percent coverage of all vascular and non-vascular plant species within a defined area is estimated and assigned to a vegetation stratum. In addition, site, environment, and soils information are collected in a standardized manner (BC Government, 2010). Table analysis approaches with the assistance of ordination and other techniques are used to group plots with similar plant communities into plant associations defined by specific diagnostic species and a defined range in habitat and vegetation physiognomy (Shimwell, 1971; Ellenberg 1988). As other local or regional classifications are created, plant associations from each are compared and combined together in a process termed correlation to create a larger geographic scope and linkages for national plant associations (MacKenzie and Meidinger, 2018). The plant association units can be scaled up and related to each other through broader functional levels based on floristic/ecological similarity (BEC/AVC) or functional/spatial factors through a combination of floristics, dominance, physiognomy, and biogeography (USNVC, 2016) (Fig. 1).

\section{Biogeoclimatic (Zonal) Classification}

To classify and identify the geographic ranges of regional-scale terrestrial subzones (Fig. 1), Pojar et al. (1987) use the zonal concept ("reference sites" in Environment Yukon, 2016), also utilized in other areas of Canada and the Arctic (e.g., Saucier et al., 1998; Ecoregions Working Group, 1989; CAVM Team, 2003; Gould et al., 2003; Jorgenson and Meidinger, 2015). The zonal concept can be traced to early work in Russia attributed to Dokuchaev (1899), which linked broad patterns in soil types to regional climatic gradients. This concept was brought to North America by early soil scientists such as Marbut (1935). Zonal sites have defined physical characteristics, which are believed to best reflect regional climates, such as being positioned on moderate, neutral aspect slopes and having well-drained soils of at least medium depth with loamy texture and low coarse fragment content. As a result, the late seral plant communities that occur on zonal sites are presumed to best reflect the ecological potential of regional climates (Pojar et al., 1987; Ecoregions Working Group, 1989; CAVM Team, 2003).

The zonal concept has been used to characterize and locate the boundaries of the global-scale Arctic subzones of the Circum-Arctic Vegetation Map based on zonal ecosystem physiognomy (CAVM Team, 2003). Another approach is the phytogeographic zonation of floristic provinces developed by Yurtsev (1994), which separates areas with different floristic elements and distributions. The CASBEC uses a zonal plant community classification that can be developed to identify, classify, and map terrestrial biogeoclimatic subzones based on overall floristic similarity of the zonal ecosystems following the approach of Klinka et al. $(1979,1991,1996)$. This approach effectively merges and refines the subzone and floristic province concepts of the CAVM Team (2003). In practice, the zonal concept needs to be adapted regionally to account for distinct differences in late seral zonal ecological communities within the same regional climate because of differences in predominant parent material; for example, calcareous versus noncalcareous substrates (Walker, 2002) or by dominating successional drivers such as high frequency fire (Arseneault and Payette, 1992; Payette and Delwaide, 2003; Girard et al., 2008). 


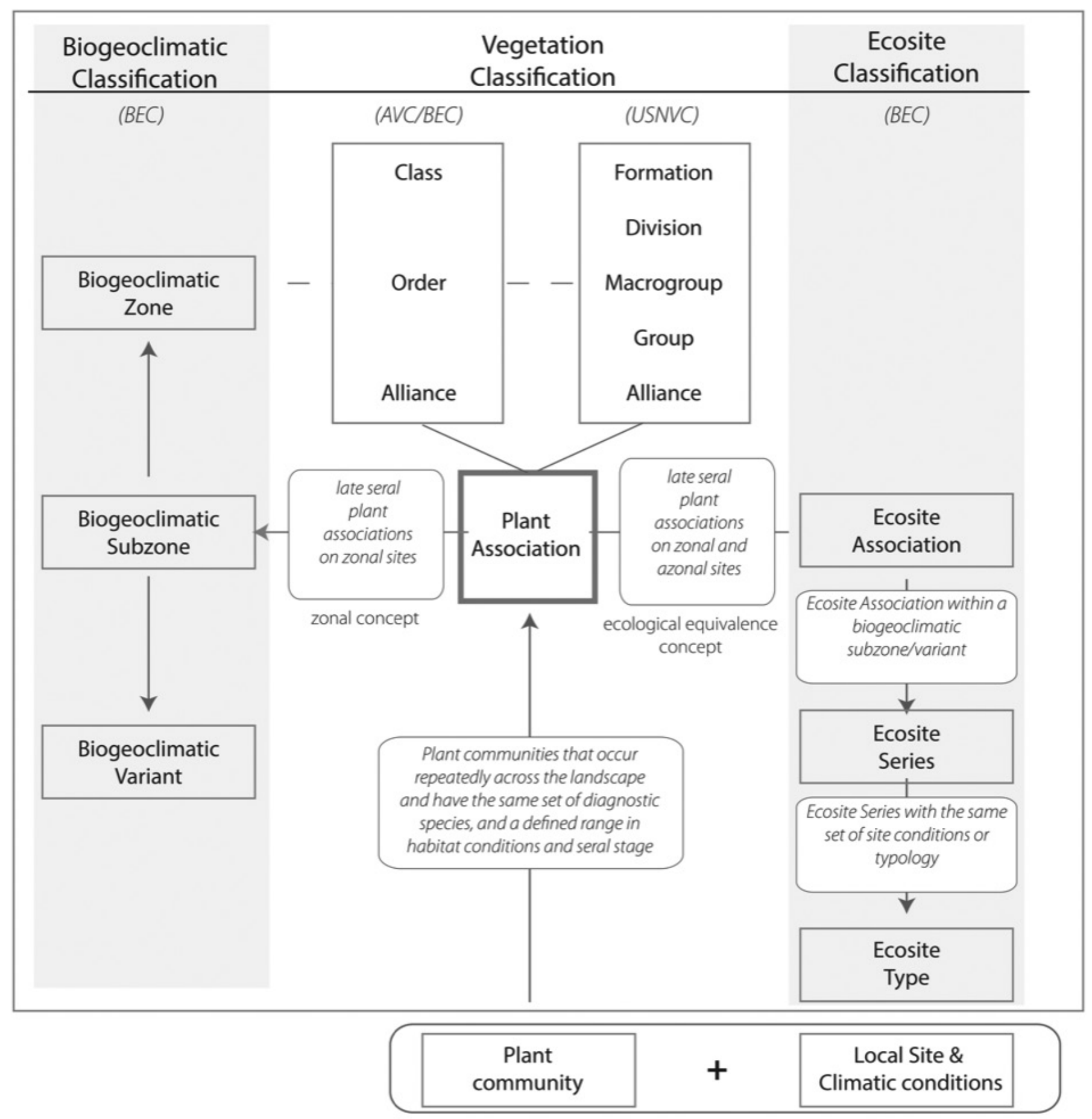

\section{An individual Terrestrial Ecological Community}

FIG. 1. The CASBEC framework showing Biogeoclimatic and Ecosite Classification linkages to the central Vegetation Classification, including to the higher units of the Biogeoclimatic Ecosystem Classification (BEC), Arctic Vegetation Classification (AVC) and to the United States National Vegetation Classification (USNVC). The Plant Association is central to the CASBEC and links to Biogeoclimatic and the Ecosite Classifications through the zonal and ecological equivalence concepts, respectively.

\section{Ecological Site (Ecosite) Classification}

The mosaic of ecological communities that we observe as we travel across a Subarctic or Arctic landscape manifests changes in ecological site conditions and reflects disturbance history of the area. In the CASBEC, ecological sites or "ecosites" describe those areas of the landscape where the sum total of the environmental factors that interact to determine vegetation composition, structure and composition are equivalent, as expressed by the 
occurrence of similar late seral plant communities. Those ecosites that support the same late seral plant association, regardless of the biogeoclimatic subzone in which they occur, are considered ecologically equivalent and are used in the CASBEC to define the ecosite association (Fig. 1). Ecosite associations that occur within the same biogeoclimatic subzone are considered to be ecologically and climatically equivalent, that is, they occur within the same regional climate and are classified as ecosite series within that subzone. Ecosite series can be further refined locally into ecosite types based on differences in site morphology. For example, the zonal ecosite series in the CHARS Experimental and Reference Area (CHARS ERA) is classified into several ecosite types based on differences in the coverage of stones at the surface, which ranges from very low coverage $(<5 \%)$ to very high $(>50 \%-75 \%)$. Ecosite types capture the key environmental processes and site morphological features that determine site productivity and are a strong basis for site-based interpretations such as habitat mapping, ecosystem modelling, for designing and interpreting research and monitoring experiments, and for land-use applications such as site sensitivity and trafficability. Thus the concept of ecological equivalence permits the field identification and classification of enduring ecological sites affected by similar driving ecological processes, with similar ecosystem productivities, supporting relatively predictable plant communities, and consequently providing a similar range of ecological services.

In the Arctic, most vegetation communities can be considered late seral given the infrequency of standreplacing disturbance, so that ecosites are readily identifiable by the plant association that occurs. In the Subarctic however, stand-replacing wildfire is common and only stands in the late seral stage are used to classify the ecosite. A series of relatively predictable seral plant associations will develop following stand-replacing fire on a particular ecosite, and together these plant associations represent the ecological potential of the site. There are situations in Subarctic landscapes where high frequency, repeated stand-replacing fire will create disclimax, late seral stands on zonal ecosites (Arseneault and Payette, 1992). Cases of zonal disclimax will need to be recognized in the course of delineating and defining bioclimate zones and subzones for establishing a regional ecosystem classification. Broad differences in the lithologies of soil material can also complicate zonal classifications. For example, in the Cambridge Bay area of western Nunavut, the CAVM Subzone D occurs on southern Victoria Island on base-rich limestone tills and extends to the southern, mainland area of the same subzone where granitic rock and tills of the Canadian Shield dominate. As a result, two very different sets of azonal and zonal ecosystems develop within the same regional climate, so that, in this situation, two separate ecosystem classifications are required to account for this overriding difference in bedrock composition.
All ecosite series within a biogeoclimatic subzone occurring on non-zonal site conditions are termed "azonal." Azonal site conditions modify the effects of regional climates because of factors such as rapid soil drainage on coarse, rocky sites, persistent seepage or waterlogging (wetlands) in depressions, deep winter snow accumulation, excessive wind exposure, or seasonal flooding. These azonal site conditions support distinctive azonal ecological communities comprised of species co-adapted to each set of recurrent site conditions. The functional linkages between the biotic and abiotic components of ecological communities provide the basis for assessing and extrapolating the role of ecological processes in determining their nature and distribution. Typically, these processes are inferred from a qualitative analysis of the ecosystem data collected in the field, such as soil depth, texture, coarse fragment content, depth to permafrost, and the presence of soil mottling or gleying for mineral soils, or the nature and depth of organic strata and water tables in organic soils. Site factors are also part of the overall description and include assessments and measurements of slope angle and slope position (e.g., upper, mid, lower, toe, depression), site aspect and exposure to sun and wind, elevation, landform, as well as observations and assessments of other relevant factors such as the presence, frequency and duration of riverine or estuarine flooding, sedimentation and erosion, snow bed persistence, or soil instability (see BC Government, 2010 for standardized methods). In CASBEC, the ecological relationships among ecosites within a biogeoclimatic subzone are presented on an environmental grid with the two most dominant environmental axes derived from site and soils data. In Figure 2, an edatopic grid developed for the southwestern Yukon shows the distribution of ecosite series in the Boreal Subalpine Low (BOsl) Subzone along the two most important ecological gradients in that region-relative soil moisture regime and soil nutrient regime.

\section{MODELLING AND MONITORING THE ECOLOGICAL EFFECTS OF CLIMATE CHANGE}

The concepts outlined above to develop a CASBEC that links late seral plant communities to characteristic ecological sites assume development under conditions of relative climatic stability. This stability is supported by the estimated stationarity of North American and Eurasian tree lines for the last 3000 to 4000 years (Lavoie and Payette, 1996; MacDonald et al., 2000; Payette, 2007). Climatic consistency has helped create the distinctive patterns of terrestrial ecological communities and physiognomic boundaries (e.g., tree lines and shrub lines) that we see in the Arctic today (CAVM Team, 2003). Under these relatively constant environmental conditions, correlative relationships between ecological communities and regional climates and other driving site factors, including mean summer temperature, snow regimes, ground ice processes, and active layer depths have been established. 
Soil Nutrient Regime (SNR)

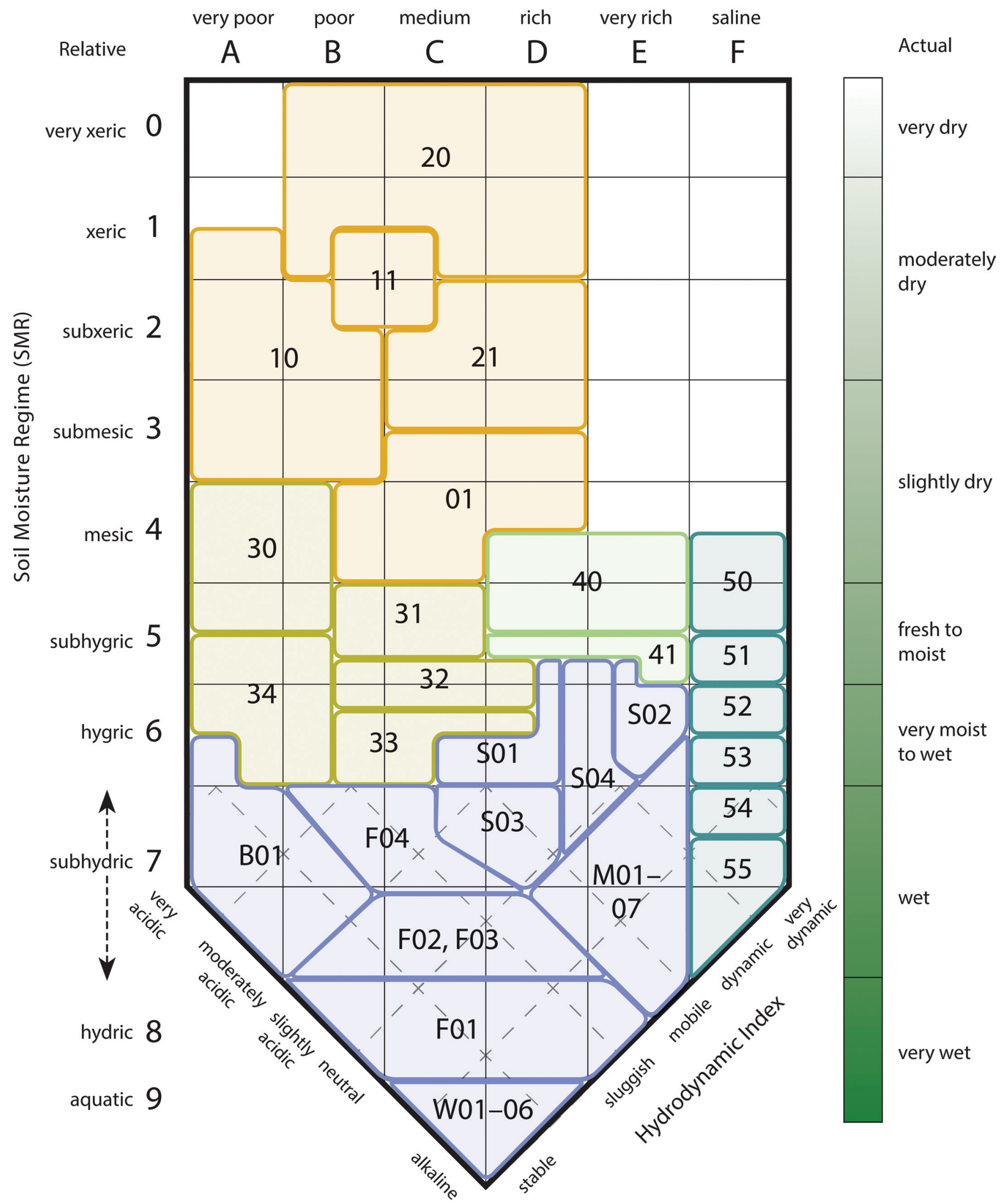

FIG. 2. Example of an edatopic grid showing the matrix of ecosite series classified in the Boreal Subalpine Low (BOsl) Subzone in southwestern Yukon. Axes include soil nutrient regime, soil moisture regime, and two axes of wetland classification — a hydrodynamic index (flooding characteristics) and a pH gradient. Figure courtesy of Environment Yukon (2017). 
It is clear now that this overall consistency in climate and related drivers is changing, and it is to be expected that Arctic and Subarctic plant communities will change in response (ACIA, 2005; SWIPA, 2011; Pearson et al., 2013). For example, the in situ relative dominance of species is already changing in many ecological communities across the Arctic (Sturm et al., 2005; Tape et al., 2006, 2012; Hudson et al., 2011; Myers-Smith et al., 2011; Elmendorf et al., 2012a, 2015; Henry et al., 2012; Zamin and Grogan, 2012, Fraser et al., 2014; Zamin et al., 2014), and we can expect that vegetation community composition will eventually change as well, with southern species slowly replacing Arctic and Subarctic species from south to north. Since these changes are only beginning to happen, classification of these persistent ecosystems will set an ecological baseline from which climate change effects can be compared and observed. Long-term monitoring of plant communities on similar ecosites can thus provide a standardized approach to help document climate-driven terrestrial ecosystem change.

\section{APPLICATIONS OF CASBEC TO ARCTIC BIODIVERSITY MONITORING}

The amplification of climate warming at more than double the global average in northern latitudes (ACIA, 2005; Serreze et al., 2009; IPCC, 2013) means that abiotic and biotic components of Canada's Subarctic and Arctic ecosystems are changing and will continue to change in ways that are highly complex and difficult to predict with any certainty (Francis et al., 2009; Lawler et al., 2009; Derksen et al., 2012). Because of this high uncertainty, many summary reports on climate-driven change at high latitudes have recommended the immediate establishment of coordinated and integrated monitoring networks that can generate timely information on how ongoing climate change is driving ecological change in northern Canada (ACIA, 2005; SWIPA, 2011; Bidwell et al., 2013).

Under the Arctic Council's Conservation of Arctic Flora and Fauna (CAFF) Working Group, monitoring programs have been developed for marine, freshwater, and terrestrial ecosystems, as three components of the CAFF Circumpolar Biodiversity Monitoring Program (CBMP). General monitoring questions identified in the development of the CAFF CBMP Terrestrial Biodiversity Monitoring Plan (Christensen et al., 2013) provide coordinated direction to inform local monitoring questions. Through the CBMP Terrestrial Expert Monitoring Group process, essential and recommended Focal Ecosystem Components (FECs) of terrestrial ecosystems have been selected by a team of specialists in Arctic terrestrial ecosystems to create an internationally agreed-upon set of monitoring indicators that can be used to assess and report the condition of terrestrial biodiversity across the circumpolar North. An approach outlining design options for plot layout and transect locations is described in the Arctic Regions
Essential Components (AREC) Integrated Monitoring Design (Ibarguchi et al., 2015). Here we discuss how CASBEC captures ecological variability at regional to local scales, and provides an ecosystem template for producing an effective local, regional, national, and international monitoring sample design that could underlie coordinated national and international monitoring efforts.

\section{Capturing Regional Scale Ecological Variability}

A long-range goal for the CASBEC is to develop biogeoclimatic maps like the products developed in British Columbia (BECP, 2018) and more recently in Yukon (Environment Yukon, 2016). At this time, the CAVM subzone classification and mapping (CAVM Team, 2003) can be used to stratify regional climates in the Arctic, and the Ecoclimatic Regions of Canada map (Ecoregions Working Group, 1989) can be used for the Canadian Subarctic. However, neither of these products is at an appropriate scale to address topographic variability or biogeographic- and precipitation-driven ecosystem variability across the Canadian North. CASBEC is being developed at this time to provide an appropriate scale of bioclimatic stratification that will recognize ecologically important regional variability by establishing a network of monitoring observatories to represent, as much as possible, the range of Subarctic and Arctic regional-scale climatic variability. This representation is critical for ensuring that a national or international monitoring network can track and report on ecological change across the range of Arctic and Subarctic bioclimates.

\section{Long-term Question-based Experiments}

At each observatory where long-term monitoring is established, a recommended approach would be to use the CASBEC classification and map products as resources in the study design of question-based monitoring experiments (Lindenmeyer and Likens, 2010). Question-based (or hypothesis-based) monitoring is essentially a series of replicated long-term experiments that measure changes in important ecosystem indicators and the abiotic drivers that control them against hypothesized outcomes. Work ongoing under the International Tundra Experiment (Henry and Molau, 1997) meets many of the criteria for questionbased monitoring.

In the Intensive Monitoring Area (IMA) of the CHARS ERA near Cambridge Bay, Nunavut, we are planning to implement long-term monitoring experiments that link key environmental drivers such as air and soil temperature, precipitation and soil moisture, active layer depth, and snow depth and duration to measures of vegetation response and to changes in nutrient cycling, arthropods, small mammals, and shorebirds. These long-term experiments are being designed to assess how and why terrestrial ecosystems in the IMA are changing and to permit modeled projections of how the indicators may change in the future under different 
climate scenarios. The CASBEC ecosite classification will be a key component of the experimental design of the monitoring established in the IMA, in an attempt to capture local-scale landscape variability in the response of different terrestrial ecosystems and for scaling results to regional scales.

Capturing Local-Scale Ecological Variability: The Role of the CASBEC

A preliminary classification of tundra ecosites within the CHARS ERA (Fig. 3), located in CAVM Subzone D (CAVM Team, 2003) on southeastern Victoria Island, shows the relative positions of 11 ecosite series within a two-axis (soil moisture $\times$ snow protection) chiono-edaphic grid. Each ecosite type shown in Figure 3 represents a unique group of terrestrial ecological communities, with its own set of site characteristics (e.g., soil depth and texture, active layer depth, slope and aspect), abiotic environmental drivers (e.g., the degree of seasonal flooding, soil drainage and the depth of protective winter snow), and ecological processes (e.g., rates of nutrient cycling, inter-species competition, pollination). These site characteristics, abiotic environmental drivers, and ecological processes directly and indirectly determine the productivity, structure, and species composition of the ecosite type's characteristic plant association. The ecosite classification captures localscale ecological variability and summarizes a qualitative, integrated understanding of local-scale terrestrial ecosystem patterns and processes. The classification provides the rationale for establishing more quantitative ecosystem research and monitoring, for developing interpretative classifications such as habitat suitability, and as the basis for process-based modelling of ecological change. In terms of developing an experimental design for establishing long-term monitoring experiments, the CASBEC ecosite type classification provides an ecological template for laying out monitoring plots and transects to capture local-scale ecosystem variability across the IMA landscape.

\section{Selecting Terrestrial Ecosystems for Long-term Monitoring}

In an ideal world, we would establish question-based monitoring at all 11 ecosite types in the IMA, but in practice this would be prohibitively expensive given the number of ecosite types and the considerable costs of establishing and replicating monitoring experiments that integrate a suite of monitoring measures and ecological drivers. Given this local-scale complexity, it will be necessary to either select certain ecological communities for monitoring or to combine communities (e.g., all wetland communities or all snow-protected communities) and sample across them. To prioritize local ecological communities for monitoring, one approach that utilizes CASBEC theory and products would be to select:

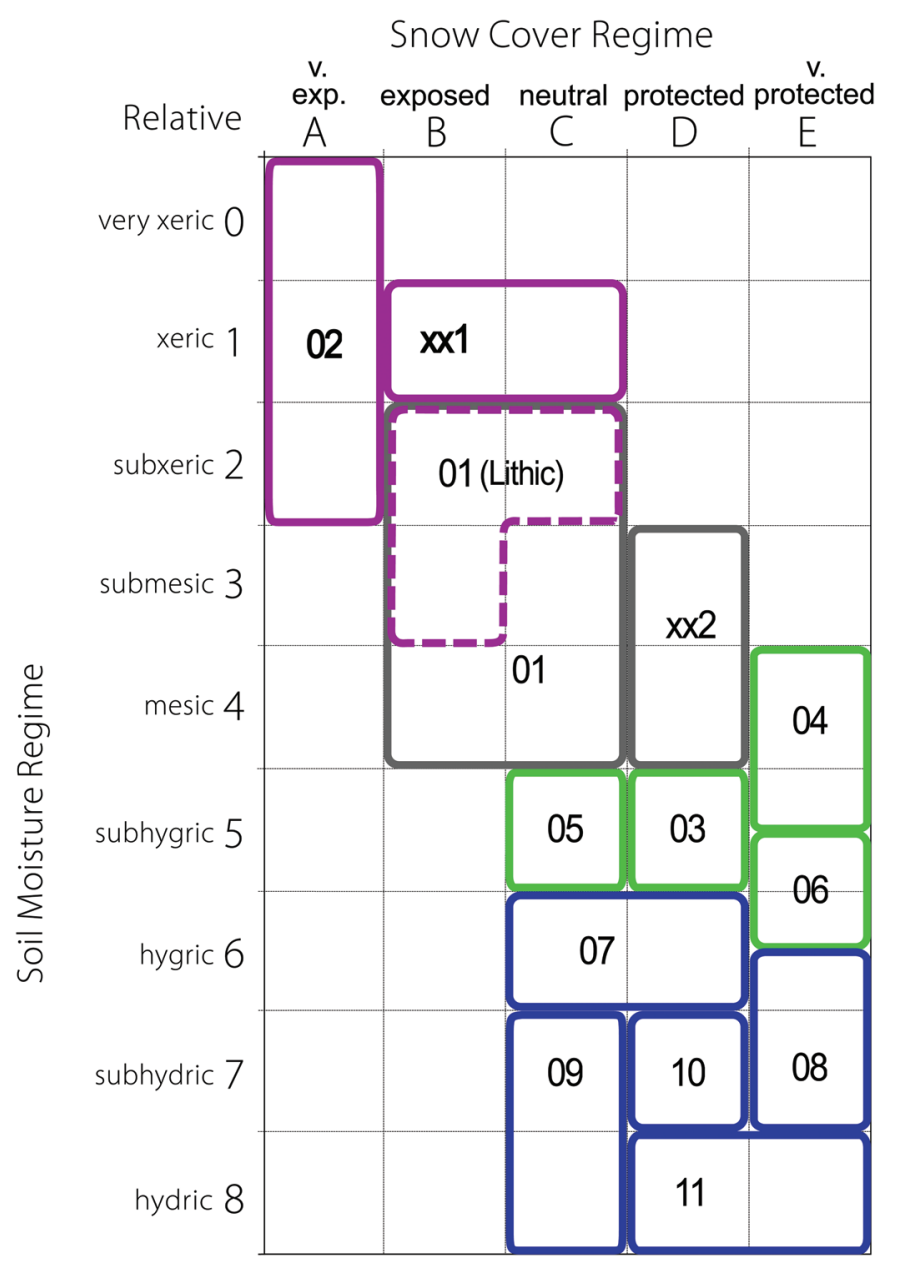

FIG. 3. Draft edatopic grid developed for the CHARS ERA (Greiner Lake Watershed) in southeastern Victoria Island (CAVM Zone D) showing the relative positions of 11 ecosite series within a two-axis (soil moisture $\times$ snow protection) chiono-edaphic grid. 'Arc' refer to ecosite series defined by plant associations correlated to the CNVC Arctic vegetation classificationthis correlation is ongoing. 01 (Arc041): Dryas integrifolia-Saxifraga oppositifolia; Carex rupestris. 02 (Arc): Saxifraga tricuspidata-Oxytropis arctobia. xx1 (Arc): Salix arctica || xx2: Dryas integrifolia-Oxytropis. 03 (Arc): Dryas integrifolia-Salix reticulata. 04 (Arc027): Cassiope tetragona-Dryas integrifolia-Salix reticulata. 05 (Arc): Dryas integrifoliaCarex aquatilis-Salix arctica. 06 (Arc): xxDryas integrifolia-Equisetum arvense-Arctous alpina \|| Salix polaris-Moss. 07 (Arc): Salix arcticaCarex aquatilis-Scorpidium. 08 (Arc): Salix richardsonii-Carex aquatilis. 09 (Arc): Carex aquatilis. 10 (Arc): Dupontia f sheri-Carex aquatilis. 11 (Arc): Arctophila fulva.

- zonal ecosite types at all monitoring observatories to provide a coordinated basis for assessing and comparing changes across regional, national, and international scales, and:

- azonal ecosite types based on international to local priorities; for example, ecological communities that are important habitat for caribou or muskoxen, climate refugia or snow bed communities important for conservation objectives, or ecological communities potentially impacted by resource development or expected to change quickly, such as moist, rich sites with a vigorous shrub component, or estuarine communities that are important staging and nesting areas for migratory shorebirds and waterfowl and may 
be impacted by rising sea levels. Other priorities may flow from ongoing research-for example, it may be a local priority to monitor ecological communities where net ecosystem carbon flux or cryosphere change is being measured.

In the IMA of the CHARS ERA, we have selected four ecosite types for intensive monitoring, based on their having the predominant areal coverage, and according to the following rationale:

Zonal Ecosite Type - 01 (Dryas integrifolia-Saxifraga oppositifolia-Carex rupestris): The Zonal Ecosite Type is that ecosystem most reflective of regional bioclimate (i.e., it is the zonal ecotype for the base-rich areas of CAVM Zone D in which the IMA is located). Monitoring the Zonal Ecosite Type thus provides an ecological basis for comparing change across Arctic biogeoclimatic subzones. The Zonal Ecosite Type is also important as habitat for collared lemmings (Dicrostonyx groenlandicus), and as a winter foraging area for Arctic hares (Lepus arcticus) and muskoxen (Ovibos moschatus).

Snow Ecosite Type - 04 (Cassiope tetragona-Dryas integrifolia-Salix reticulata): The Snow Ecosite Type is afforded the highest winter snow protection and as a result features warmer winter soils and deeper active layers and supports unique flora that would otherwise not be able to survive under prevailing winter conditions in the study area. The reliable deep snow in this ecotype also provides critical wintering areas for collared and brown lemmings (Lemmus trimucronatus), keystone species that drive the abundance of many predator species.

Shrub-sedge Fen Ecosite Type - 08 (Salix richardsonii-Carex aquatilis): The Shrub-Sedge Fen Ecosite Type supports the tallest shrub communities in the IMA, and is targeted for shrubification monitoring and NDVI-derived greening. This ecosite type also provides important summer forage for caribou (Rangifer tarandus), muskoxen, brown lemmings and Arctic hare.

Sedge Fen Ecosite Type - 09 (Carex aquatilis): The Sedge Fen Ecosite Type is the most common wetland type in the IMA and throughout the CAVM Subzone D. The Sedge Fen Ecosite Type provides important summer forage for caribou, muskoxen, brown lemmings, and Arctic hares.

\section{Monitoring Plots and Transects}

Plot-based, or transect-based approaches can be used to establish long-term, question-based monitoring experiments in terrestrial ecosystems (Ibarguchi et al., 2015). Plot-based monitoring requires replication to account for spatial or site variability of monitored ecosystem properties. Attaining high levels of confidence to assess spatial or temporal change may be difficult for highly variable measures (Elzinga et al., 1998; Lindenmeyer and Likens, 2010). The advantage of a plot-based approach centred on replicated ecosite types is that these units provide a recognizable and scalable entity controlling for ecologically important site variability and for building mechanistic models that can explore and test long-term change in the relationships among abiotic and biotic ecosystem components.

Monitoring in the central areas of ecosite type polygons may miss important changes at ecosystem boundaries (ecotones) and will miss changes in interactions among ecosystems, such as the downslope movement of soil water and nutrients. These relationships are best captured along monitoring transects situated to optimize inclusion of a range of targeted ecological communities in an area. A recommended design combines plot-based and transect approaches by establishing monitoring transects along predominant ecological gradients, such as along a dry to wet soil moisture regime gradient, and long-term experiments both in and between ecological communities. In the IMA in the CHARS ERA, we propose to combine plot-based and transect-based approaches to track change within the four selected ecosite types and in the interactions between ecosite types (Fig. 4).

\section{Ecosystem Maps and Inventory}

A sample design for the selection of ecosites to establish question-based monitoring will be constrained by logistical issues such as access, spatial orientation of ecosites, and replication requirements. The site selection process can be facilitated by using a large-scale ecosite type map generated from high-resolution satellite imagery or aerial photography, such as the one developed for the IMA in the CHARS ERA (Fig. 5). The ecosystem map delineates the spatial distributions of classified ecosite types within the IMA, and provides an ecological template to randomize and optimize the location of potential monitoring plots and transects, given monitoring priorities and logistical constraints.

A high-resolution map of ecological communities can also be used to monitor areal change at the landscape scale (e.g., expansion or shrinkage of ecological communities, changes in vegetation biomass or shrub cover, or changes in important wildlife habitat) and to link the results of the question-based monitoring to broad areas through remote sensing approaches (Fraser et al., 2011, 2014; Pearson et al., 2013; Zhang et al., 2013; Nicolsky et al., 2017). By agglomerating ecosite types and ecosite series, local-scale monitoring and derived models can be scaled up from detailed ecosite type maps using high-resolution imagery to ecotype series maps based on medium-scale imagery to cover ecologically representative regional areas (i.e., limestone-rich areas of the CAVM Subzone across southern Victoria Island).

Whatever ecological communities are selected for monitoring, or the local objectives of the monitoring program, we have presented here how a natural classification of Arctic and Subarctic terrestrial ecological communities like the CASBEC, which is grounded in a correlated 


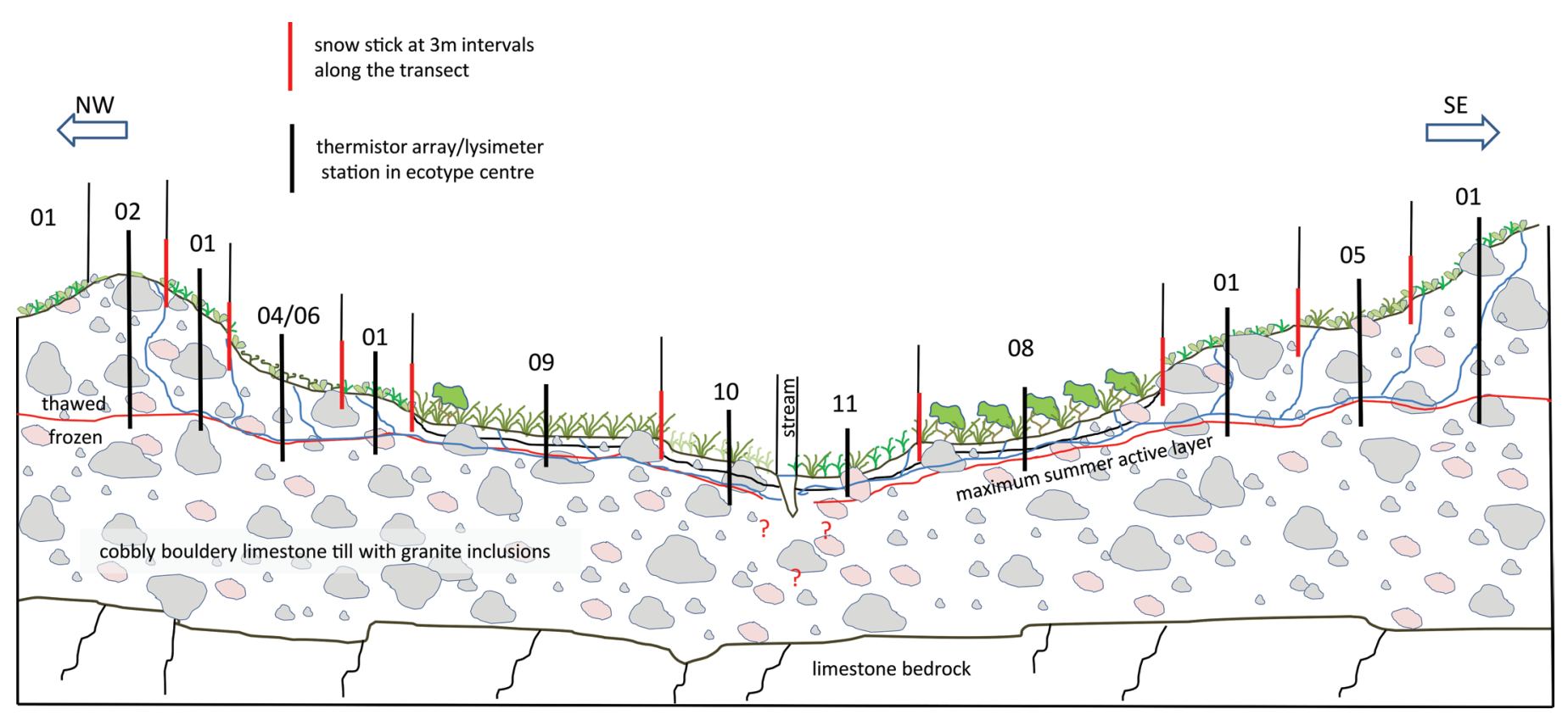

FIG. 4. Cross-sectional representation of a long-term experimental monitoring transect planned for the Intensive Monitoring Area (IMA) in the Experimental and Reference Area at the Canadian High Arctic Research Station (CHARS ERA), near Cambridge Bay, Nunavut. See Figure 3 for names of numbered ecosite series along the monitoring transect.

classification of plant communities, can act as an ecological frame to provide a clear rationale for selecting sites to monitor, to interpret monitoring results and inform research and to coordinate and compare results across northern monitoring sites in different eco-regional areas of the Canadian and circumpolar Arctic and Subarctic. CASBEC provides a standardized ecological template for coordinating regional- to local-scale monitoring by developing a common taxonomy of Arctic and Subarctic ecological communities, by summarizing key abiotic factors driving ecosystem composition, structure and productivity, and by providing a standardized approach for agglomerating local communities to scale up regionally using a range of modeling approaches and remote sensing tools.

\section{SUMMARY AND DISCUSSION}

This paper has presented the important role that a correlated classification of plant communities and their associated environmental conditions can play in providing a strong basis for developing a natural classification of ecosystems such as the CASBEC. At the core of CASBEC is a vegetation classification that organizes plant communities into plant associations and uses their geographic distributions and environmental adaptations as phytometers to distinguish regional terrestrial subzones and local-scale ecosites. A standardized and correlated vegetation classification, such as that being developed nationally through the CNVC, and eventually internationally through the AVA, can provide a standardized nomenclature for circumpolar terrestrial ecosystems to support many aspects of nationally and internationally coordinated monitoring and research.
The CASBEC approach presented here follows in the footsteps of proven and mature terrestrial ecosystem classification systems developed for forest management in southern Canada, especially the Biogeoclimatic Ecosystem Classification of British Columbia (Pojar et al., 1987) and the Quebec Forest Ecosystem Classification (Bergeron et al., 1992). The CASBEC approach is also very similar to recent developments in terrestrial ecosystem classification in Yukon (Environment Yukon, 2016), but is fundamentally different in approach compared to terrestrial ecosystem classification approaches in the Northwest Territories (Ecosystem Classification Group, 2008, 2012, 2013) and from national work on ecological land classification led by workers at Environment and Climate Change Canada (Ecological Stratification Working Group, 1995). The CASBEC and related approaches employ a bottom-up approach where floristic criteria are used to classify local-scale ecosystems, and regional ecological units (biogeoclimatic subzones and zones) are defined and mapped from a subset of local ecosystems (i.e., from the distributions of late seral, zonal ecosystems as described above). Workers in the Northwest Territories and at Environment and Climate Change Canada use a top-down approach where areas similar in landscape physiography and general vegetation physiognomy and dominant species composition are progressively divided into large-scale units-from ecozones through ecoregions to ecodistricts, down to a local-scale unit, the ecosite.

Although applications to pan-northern terrestrial monitoring are explored here, a similar argument can be made for the role of CASBEC in developing a strategic approach for implementing coordinated research across the Arctic and Subarctic. The CASBEC provides a 


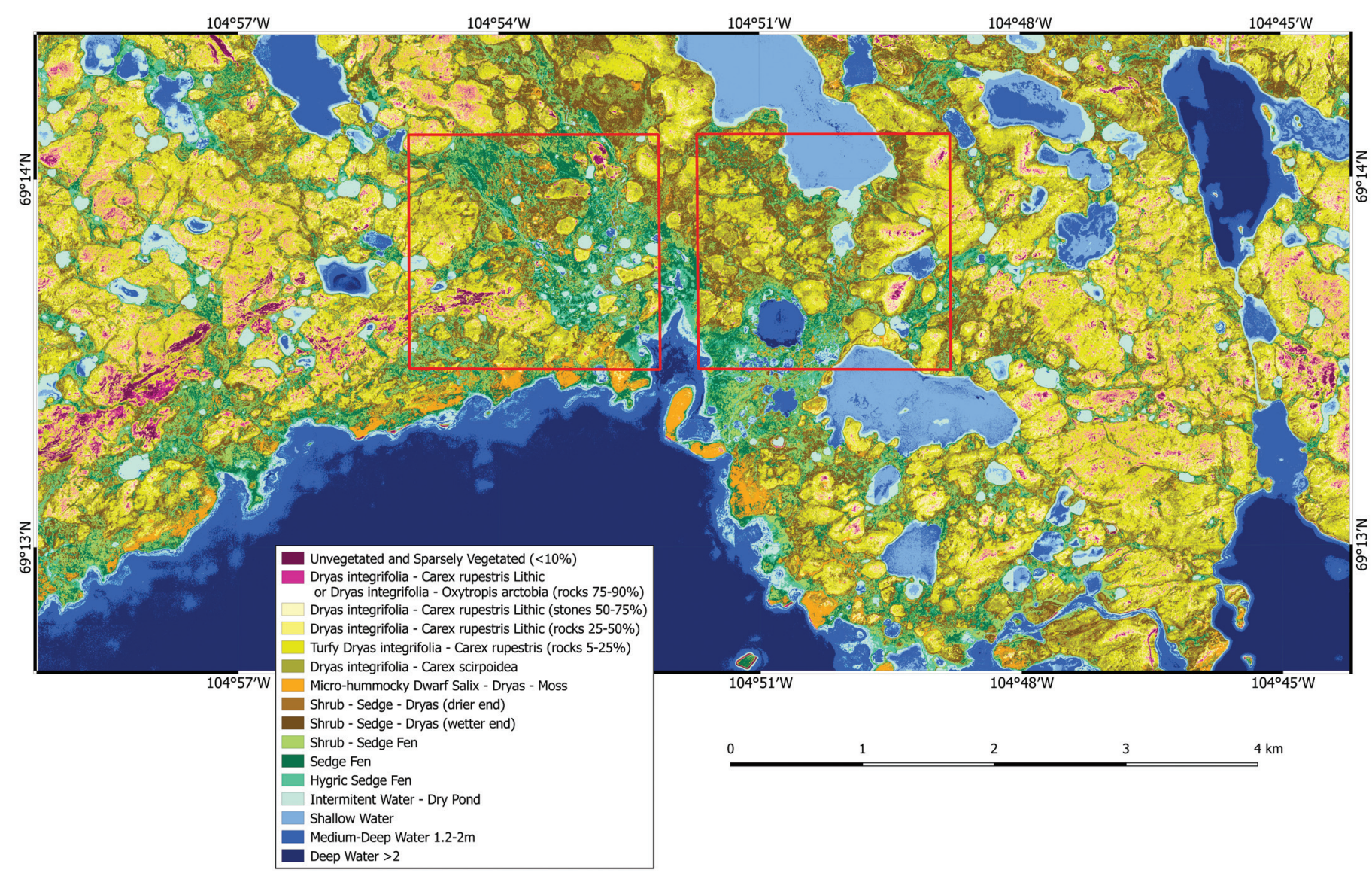

FIG. 5. Ecosite type map of the southern region of the Intensive Monitoring Area (IMA) of the Experimental and Reference Area at the Canadian High Arctic Research Station (CHARS ERA), near Cambridge Bay, Nunavut (Ponomarenko, 2017). Red squares show the extent of the two paired areas where instrumented, long-term monitoring experiments will be established.

standardized approach to classifying Arctic and Subarctic terrestrial ecological communities that includes qualitative interpretations of the processes that drive ecosystem characteristics. In the CHARS ERA, we will conduct studies to test these qualitative interpretations to lend support for quantitative, process-based ecosystem models developed to predict climate-driven changes in plant species composition and vegetation community structure, permafrost degradation, nutrient cycling, net ecosystem carbon flux, and habitat change. In that derived ecosites are linked to ecosystem drivers and are mappable, localscale process models that link changes in abiotic drivers to changes in vegetation and other community components can be scaled up regionally using remote sensing approaches to provide a broader perspective on landscape scale ecosystem change (Zhang et al., 2013; Nicolsky et al., 2017). For all of these reasons, widespread adoption of the CASBEC will provide a common language and taxonomy for interpreting, integrating, and coordinating Arctic and Subarctic monitoring, research, and land management activities across the Canadian North and around the circumpolar area.

\section{REFERENCES}

ACIA (Arctic climate impact assessment). 2005. Cambridge: Cambridge University Press.

Arseneault, D., and Payette, S., 1992. A postfire shift from lichen-spruce to lichen-tundra vegetation at tree line. Ecology 73(3):1067-1081.

https://doi.org/10.2307/1940181

BC Government. 2010. Field manual for describing terrestrial ecosystems, $2^{\text {nd }}$ ed. Land Management Handbook No. 25. Victoria: British Columbia Ministry of Forests and Range and BC Ministry of Environment.

https://www.for.gov.bc.ca/hfd/pubs/docs/Lmh/Lmh25_2015. htm

Beckingham, J.D., Nielsen, D.G., and Futoransky, V.A. 1996a. Field guide to the ecosites of the mid-boreal ecoregions of Saskachewan. Special Report 6. Edmonton, Alberta: Natural Resources Canada, Canadian Forest Service, Northwest Region, Northern Forestry Centre.

Beckingham, J.D., Corns, I.G.W., and Archibald, J.H. 1996b. Field guide to the ecosites of west central Alberta. Special Report 9. Edmonton, Alberta: Natural Resources Canada, Canadian Forest Service, Northwest Region, Northern Forestry Centre. 
BECP (Biogeoclimatic Ecosystem Classification Program). 2018. Biogeoclimatic maps (zone or subzone variant). Victoria: British Columbia Forest Service, Research Branch.

https:/www.for.gov.bc.ca/HRE/becweb/resources/maps/ index.html

Bergeron, J.-F., Saucier, J.-P., Robitaille, A., and Robert, D. 1992. Québec forest ecosystem classification program. The Forestry Chronicle 68(1):53-63.

https://doi.org/10.5558/tfc68053-1

Bidwell, D., Dietz, T., and Scavia, D. 2013. Fostering knowledge networks for climate adaptation. Nature Climate Change 3:610-611. https://doi.org/10.1038/nclimate1931

CAVM Team. 2003. Circumpolar Arctic Vegetation Map. (1:7500000 scale). Conservation of Arctic Flora and Fauna Map No. 1. Anchorage, Alaska: U.S. Fish and Wildlife Service.

Christensen, T., Payne, J., Doyle, M., Ibarguchi, G., Taylor, J., Schmidt, N.M., Gill, M., et al. 2013. The Arctic Terrestrial Biodiversity Monitoring Plan. CAFF Monitoring Series Report No. 7. Akureyri, Iceland: CAFF International Secretariat.

CNVC (Canadian National Vegetation Classification). 2015. http://cnvc-cnvc.ca/

Corns, I.G.W., and Annas, R.M. 1986. Field guide to forest ecosystems of west-central Alberta. Edmonton, Alberta: Natural Resources Canada, Canadian Forest Service, Northwest Region, Northern Forestry Centre.

Derksen, C., Smith, S.L., Sharp, M., Brown, L., Howell, S., Copland, L., Mueller, D.R., et al. 2012. Variability and change in the Canadian cryosphere. Climatic Change 115(1):59-88. https://doi.org/10.1007/s10584-012-0470-1

Dokuchaev, V.V. 1899. A contribution to the theory of natural zones: Horizontal and vertical soil zones. In Russian. St. Petersburg: Mayor's Office Press. 62 p.

Ecological Stratification Working Group. 1995. A national ecological framework for Canada. Report and national map at 1:7 500000 scale. Ottawa: Agriculture and Agri-Food Canada, Research Branch, Centre for Land and Biological Resources Research and Environment Canada, State of the Environment Directorate, Ecozone Analysis Branch.

Ecoregions Working Group. 1989. Ecoclimatic regions of Canada: First approximation. Ecological Land Classification Series, No. 23. Ottawa: Canada Committee on Ecological Land Classification, Sustainable Development Branch, Canadian Wildlife Service. 118 p.

Ecosystem Classification Group. 2008. Ecological regions of the Northwest Territories: Taiga Shield. Yellowknife: Department of Environment and Natural Resources, Government of the Northwest Territories.

- 2012. Ecological regions of the Northwest Territories: Southern Arctic. Yellowknife: Department of Environment and Natural Resources, Government of the Northwest Territories. 2013. Ecological regions of the Northwest Territories: Northern Arctic. Yellowknife: Department of Environment and Natural Resources, Government of the Northwest Territories.

Ellenberg, H. 1988. Vegetation ecology of Central Europe, $4^{\text {th }}$ ed. Cambridge: Cambridge University Press. 731 p.
Elmendorf, S.C., Henry, G.H.R., Hollister, R.D., Björk, R.G., Boulanger-Lapointe, N., Cooper, E.J., Cornelissen, J.H.C., et al. 2012. Plot-scale evidence of tundra vegetation change and links to recent summer warming. Nature Climate Change $2: 453-457$.

https://doi.org/10.1038/nclimate1465

Elmendorf, S.C., Henry, G.H.R., Hollister, R.D., Fosaa, A.M., Gould, W.A., Hermanutz, L., Hofgaard, A., et al. 2015. Experiment, monitoring, and gradient methods used to infer climate change effects on plant communities yield consistent patterns. Proceedings of the National Academy of Sciences 112(2):448-452.

https://doi.org/10.1073/pnas.1410088112

Elzinga, C.L., Salzer, D.W., and Willoughby, J.W. 1998. Measuring \& monitoring plant populations. BLM Technical Reference 1730-1. Denver, Colorado: Bureau of Land Management.

Environment Yukon. 2016. Yukon ecological and landscape classification and mapping guidelines, Version 1.0. Edited by Flynn, N., and Francis, S. Whitehorse: Department of Environment, Government of Yukon.

- 2017. Southern Lakes Boreal Low Subzone (BOLsl): A field guide to ecosite identification. Boreal Low Zone Series. Whitehorse: Department of Environment, Government of Yukon.

Francis, J.A., White, D.M., Cassano, J.J., Gutkowski, W.J., Jr., Hinzman, L.D., Holland, M.M., Steele, M.A., and Vorosmarty, C.J. 2009. An Arctic hydrologic system in transition: Feedbacks and impacts on terrestrial, marine, and human life. Journal of Geophysical Research 114, G04019.

https://doi.org/10.1029/2008JG000902

Fraser, R.H., Olthof, I., Carrière, M., Deschamps, A., and Pouliot, D. 2011. Detecting long-term changes to vegetation in northern Canada using the Landsat satellite image archive. Environmental Research Letters 6(4), 045502.

https://doi.org/10.1088/1748-9326/6/4/045502

Fraser, R.H., Lantz, T.C., Olthof, I., Kokelj, S.V., and Sims, R.A. 2014. Warming-induced shrub expansion and lichen decline in the western Canadian Arctic. Ecosystems 17(7):1151-1168. https://doi.org/10.1007/s10021-014-9783-3

Girard, F., Payette, S., and Gagnon, R. 2008. Rapid expansion of lichen woodlands within the closed-crown boreal forest zone over the last 50 years caused by stand disturbances in eastern Canada. Journal of Biogeography 35(3):529-537. https://doi.org/10.1111/j.1365-2699.2007.01816.x

Gould, W.A., Walker, D.A., and Biesboer, D. 2003. Combining research and education: Bioclimatic zonation across a Canadian Arctic transect. Arctic 56(1):45-54.

https://doi.org/10.14430/arctic601

Henry, G.H.R., and Molau, U. 1997. Tundra plants and climate change: The International Tundra Experiment (ITEX). Global Change Biology 3(S1):1-9. https://doi.org/10.1111/j.1365-2486.1997.gcb132.x

Henry, G.H.R., Harper, K.A., Chen, W., Deslippe, J.R., Grant, R.F., Lafleur, P.M., Lévesque, E., Siciliano, S.D., and Simard, S.W. 2012. Effects of observed and experimental climate change on terrestrial ecosystems in northern Canada: Results from the Canadian IPY program. Climatic Change 115(1):207-234. https://doi.org/10.1007/s10584-012-0587-1 
Hills, G.A., and Pierpoint, G. 1960. Forest site evaluation in Ontario. Research Report 42. Toronto: Ontario Department of Lands and Forests. 66 p.

Hudson, J.M.G., Henry, G.H.R., and Cornwell, W.K. 2011. Taller and larger: Shifts in Arctic tundra leaf traits after 16 years of experimental warming. Global Change Biology 17(2):1013-1021. https://doi.org/10.1111/j.1365-2486.2010.02294.x

Ibarguchi, G., Doyle, M., Murray, M., Beamish, A., Brooker, A., Carpenter, M., Ernst, C., et al. 2015. Arctic Regions Essential Components (AREC) Integrated Monitoring Design. Integrated Arctic site-based monitoring design: Freshwater and terrestrial ecosystems (Version: 2015-03-31). Final report for Environment Canada. Calgary, Alberta: Arctic Institute of North America, University of Calgary.

IPCC (Intergovernmental Panel on Climate Change). 2013. Climate change 2013: The physical science basis. Working Group I Contribution to the Fifth Assessment Report of the Intergovernmental Panel on Climate Change. Cambridge: Cambridge University Press. https://doi.org/10.1017/CBO9781107415324

Jennings, M., Faber-Langendoen, D., Peet, R., Loucks, O., GlennLewin, D., Damman, A., Barbour, M., et al. 2004. Guidelines for describing associations and alliances of the U.S. National Vegetation Classification, Version 4. Washington, D.C.: The Ecological Society of America Vegetation Classification Panel. http://vegbank.org/vegdocs/panel/NVC_guidelines_v4.pdf

Jennings, M.D., Faber-Langendoen, D., Loucks, O.L., Peet, R.K., and Roberts, D. 2009. Standards for associations and alliances of the U.S. National Vegetation Classification. Ecological Monographs 79(2):173-199.

https://doi.org/10.1890/07-1804.1

Jorgensen, T., and Meidinger, D. 2015. The Alaska Yukon region of the Circumboreal Vegetation Map (CBVM). CAFF Strategies Series Report. Akureyri, Iceland: Conservation of Arctic Flora and Fauna.

Klinka, K., Nuszdorfer, F.C., and Skoda, L. 1979. Terrestrial units of central and southern Vancouver Island. Victoria, British Columbia: Ministry of Forests. 120 p.

Klinka, K., Pojar, J., and Meidinger, D.V. 1991. Revision of biogeoclimatic units of coastal British Columbia. Northwest Science 65(1):32-47.

Klinka, K., Qian, H., Pojar, J., and Meidinger, D.V. 1996. Classification of natural forest communities of coastal British Columbia. Vegetatio 125(2):149-168. https://doi.org/10.1007/BF00044648

Krajina, V.J. 1959. Terrestrial zones in British Columbia. Botanical Series No. 1. Vancouver: Department of Botany, University of British Columbia.

- 1965. Terrestrial zones in British Columbia. Ecology of Western North America 1:1-17.

Lavoie, C., and Payette, S. 1996. The long-term stability of the boreal forest limit in Subarctic Quebec. Ecology 77(4):1226-1233.

https://doi.org/10.2307/2265591
Lawler, J.J., Shafer, S.L., White, D., Kareiva, P., Maurer, E.P., Blaustein, A.R., and Bartlein, P.J. 2009. Projected climateinduced faunal change in the Western Hemisphere. Ecology 90(3):588-597.

https://doi.org/10.1890/08-0823.1

Lee, H.T., Bakowsky, W.D., Riley, J., Bowles, J., Puddister, M., Uhlig, P., and McMurray, S. 1998. Ecological land classification for southern Ontario: First approximation and its application. SCSS Field Guide FG-02. North Bay: Ontario Ministry of Natural Resources, Southcentral Science Section.

Lévesque, E., MacKenzie, W.H., and Henry, G.H.R. 2013. Vegetation data available for classification of Canadian Arctic sites. In: Walker, D.A., Breen, A.L., Raynolds, M.K., and Walker, M.D., eds. Arctic Vegetation Archive (AVA) Workshop, 14-16 April 2013, Krakow, Poland. CAFF Proceeding Series Report \#10. Akureyri, Iceland: CAFF International Secretariat. $71-74$.

Lindenmayer, D.B., and Likens, G.E. 2010. Effective ecological monitoring. London: CSIRO Publishing and Earthscan.

MacDonald, G.M., Velichko, A.A., Kremenetski, C.V., Borisova, O.K., Goleva, A.A., Andreev, A.A., Cwynar, L.C., et al. 2000. Holocene treeline history and climate change across northern Eurasia. Quaternary Research 53(3):302-311. https://doi.org/10.1006/qres.1999.2123

MacKenzie, W.H. 2013. A data compilation of Canadian Arctic vegetation relevé data and preliminary classification. In: Walker, D.A., Breen, A.L., Raynolds, M.K., and Walker, M.D., eds. Arctic Vegetation Archive (AVA) Workshop, 14-16 April 2013, Krakow, Poland. CAFF Proceeding Series Report \#10. Akureyri, Iceland: CAFF International Secretariat. 75.

MacKenzie, W.H., and Meidinger, D.V. 2018. The Biogeoclimatic Ecosystem Classification Approach: An ecological framework for vegetation classification. Phytoceonologia 48(2):203-213. https://doi.org/10.1127/phyto/2017/0160

Marbut, C.F. 1935. The soils of the United States. USDA Atlas on American Agriculture, Part III. Washington, D.C.: Government Printing Office. 98 p.

Matson, B.E., and Power, R.G. 1996. Developing an ecological land classification for the Fundy Model Forest, southeastern New Brunswick, Canada. Environmental Monitoring and Assessment 39(1-3):149-172.

https://doi.org/10.1007/BF00396142

McLaughlan, M.S., Wright, R.A., and Jiricka, R.D. 2010. Field guide to the ecosites of Saskatchewan's provincial forests. Prince Albert: Saskatchewan Ministry of Environment, Forest Service. $338 \mathrm{p}$.

McLennan, D.S., Wagner, J., MacKenzie, W.H., Ponomarenko, S., and Meidinger, D. In press. The Canadian Arctic-Subarctic Biogeoclimatic Ecosystem Classification (CASBEC). Structure, mapping and applications. Cambridge Bay, Nunavut: Aqhiliat.

Meades, W.J., and Moores, L. 1989. Forest site classification manual: A field guide to the Damman forest types of Newfoundland. Forest Resource Development Agreement (FRDA) Report 003. Corner Brook: Newfoundland Department of Forestry and Agriculture. 
Meidinger, D., and Pojar, J. 1991. The ecosystems of British Columbia. Special Report No. 6. Victoria, British Columbia: Ministry of Forests.

Mueller-Dombois, D., and Ellenberg, H. 1974. Aims and methods of vegetation ecology. New York: John Wiley.

Myers-Smith, I.H., Forbes, B.C., Wilmking, M., Hallinger, M., Lantz, T., Blok, D., Tape, K.D., et al. 2011. Shrub expansion in tundra ecosystems: Dynamics, impacts and research priorities. Environmental Research Letters 6(4), 045509. https://doi.org/10.1088/1748-9326/6/4/045509

Neily, P.D., Quigley, E., Benjamin, L., Stewart, B., and Duke, T. 2003. Ecological land classification for Nova Scotia. Volume 1 - Mapping Nova Scotia's terrestrial ecosystems. Report DNR 2003-2. Halifax: Nova Scotia Department of Natural Resources, Renewable Resources Branch.

Nicolsky, D.J., Romanovsky, V.E., Panda, S.K., Marchenko, S.S., and Muskett, R.R. 2017. Applicability of the ecosystem type approach to model permafrost dynamics across the Alaska North Slope. Journal of Geophysical Research: Earth Surface 122(1):50-75. https://doi.org/10.1002/2016JF003852

Payette, S. 2007. Contrasted dynamics of northern Labrador tree lines caused by climate change and migrational lag. Ecology 88(3):770-780. https://doi.org/10.1890/06-0265

Payette, S., and Delwaide, A. 2003. Shift of conifer boreal forest to lichen-heath parkland caused by successive stand disturbances. Ecosystems 6(6):540-550.

https://doi.org/10.1007/PL00021507

Pearson, R.G., Phillips, S.J., Loranty, M.M., Beck, P.S.A., Damoulas, T., Knight, S.J., and Goetz, S.J. 2013. Shifts in Arctic vegetation and associated feedbacks under climate change. Nature Climate Change 3:673-677.

https://doi.org/10.1038/NCLIMATE1858

Pojar, J., Klinka, K., and Meidinger, D.V. 1987. Biogeoclimatic ecosystem classification in British Columbia. Forest Ecology and Management 22:119-154.

Ponomarenko, S. 2017. Detailed ecosystem classification and mapping in the Intensive Monitoring Area of the Canadian High Arctic Research Station, Cambridge Bay, Nunavut. Contract report to Polar Knowledge Canada. Cambridge Bay, Nunavut.

Ponomarenko, S., and Alvo, R. 2001. Perspectives on developing a Canadian classification of ecological communities. Information Report ST-X-18E. Ottawa: Natural Resources Canada, Canadian Forest Service, Headquarters, Science Branch.

http://cfs.nrcan.gc.ca/pubwarehouse/pdfs/18073.pdf

Saucier, J.-P., Bergeron, J.-F., Grondin, P., and Robitaille, A. 1998. The land regions of southern Quebec (3rd version). One element in the Hierarchical Land Classification System developed by the Ministère des Resources Naturelles du Québec. Québec City.

Serreze, M.C., Barrett, A.P., Stroeve, J.C., Kindig, D.N., and Holland, M.M. 2009. The emergence of surface-based Arctic amplification. The Cryosphere 3:11-19.

https://doi.org/10.5194/tc-3-11-2009
Shimwell, D.W. 1971. The description and classification of vegetation. London: Sidgwick and Jackson. 322 p.

Sims, R.A., Towill, W.D., Baldwin, K.A., and Wickware, G.M. 1989. Field guide to the forest ecosystem classification for northwestern Ontario program. Sault Ste. Marie: Ontario Ministry of Natural Resources, Canadian Forestry Service.

Sturm, M., Schimel, J., Michaelson, G., Welker, J.M., Oberbauer, S.F., Liston, G.E., Fahnestock, J., and Romanovsky, V.E. 2005. Winter biological processes could help convert Arctic tundra to shrubland. Bioscience 55(1):17-26.

https://doi.org/10.1641/0006-3568(2005)055[0017:wbpchc]2.0. $\operatorname{co} ; 2$

Sukachev, V. 1960. The correlation between the concepts "forest ecosystem" and "forest biogeocoenose" and their importance for the classification of forests. Silva Fennica 105:94-97.

Sukachev, V.N., and Dylis, N. 1968. Fundamentals of forest biogeocoenology. Translated by J.M. MacLennan. Edinburgh: Oliver and Boyd.

SWIPA (Snow, Water, Ice and Permafrost in the Arctic). 2011. Climate change and the cryosphere. SWIPA Scientific Assessment Report. Oslo: Arctic Monitoring and Assessment Program.

Tape, K., Sturm, M., and Racine, C. 2006. The evidence for shrub expansion in northern Alaska and the Pan-Arctic. Global Change Biology 12(4):686-702.

https://doi.org/10.1111/j.1365-2486.2006.01128.x

Tape, K.D., Hallinger, M., Welker, J.M., and Ruess, R.W. 2012. Landscape heterogeneity of shrub expansion in Arctic Alaska. Ecosystems 15(5):711-724.

https://doi.org/10.1007/s10021-012-9540-4

Teplyakov, V.K., Kuzmichev, P., Baumgartner, D.M., and Everitt, R.L. 1998. A history of Russian forestry and its leaders. Pullman: Washington State University, Department of Natural Resources.

USNVC (United States National Vegetation Classification). 2016. The U.S. National Vegetation Classification: Your guide to inventorying natural and cultural plant communities.

http://usnvc.org/

Walker, D.A. 2002. Hierarchical subdivision of Arctic tundra based on vegetation response to climate, parent material, and topography. Global Change Biology 6(S1):19-34.

https://doi.org/10.1046/j.1365-2486.2000.06010.x

_., ed. 2014. Proceedings of the Alaska Arctic Vegetation Archive Workshop, 14-16 October 2013, Boulder, Colorado. CAFF Proceeding Series Report \#11. Akureyri, Iceland: CAFF International Secretariat.

Walker, D.A., and Raynolds, M.K., eds. 2011. An International Arctic Vegetation Database: A foundation for pan-Arctic biodiversity studies. CAFF Strategy Series Report \#5. Akureyri, Iceland: CAFF International Secretariat.

Walker, D.A., Raynolds, M.K., Daniëls, F.J.A., Einarsson, E., Elvebakk, A., Gould, W.A., Katenin, A.E., et al. 2005. The Circumpolar Arctic Vegetation Map. Journal of Vegetation Science 16(3):267-282.

https://doi.org/10.1111/j.1654-1103.2005.tb02365.x 
Walker, D.A., Alsos, I.G., Bay, C., Boulanger-Lapointe, N., Breen, A.L., Bültmann, H., Christensen, T., et al. 2013. Rescuing valuable Arctic vegetation data for biodiversity models, ecosystem models and a Pan-Arctic vegetation classification. Arctic 66(1):133-137. https://doi.org/10.14430/arctic4281

Walker, D.A., Daniëls, F.A., Matveyeva, N.V., Šibík, J., Walker, M.D., Breen, A.L., Druckenmiller, L.A., et al. 2018. Circumpolar Arctic vegetation classification. Phytocoenologia 48(2):181-201. https://doi.org/10.1127/phyto/2017/0192

Walker, M.D., Daniëls, F.J.A., and van der Maarel, E., eds. 1994. Circumpolar Arctic vegetation. Special issue based on contributions presented at the International Workshop on Classification of Arctic Vegetation, 5-9 March 1992, INSTAAR, University of Colorado, Boulder, Colorado. Journal of Vegetation Science 5(6):757-920.

Whittaker, R.H. 1962. Classification of natural communities. Botanical Review 28(1):1-239.

- 1973. Ordination and classification of communities. Handbook of Vegetation Science 5. The Hague: Dr. W. Junk B.V.

Yurtsev, B.A. 1994. Floristic division of the Arctic. Journal of Vegetation Science 5(6):765-776. https://doi.org/10.2307/3236191
Zamin, T.J., and Grogan, P. 2012. Birch shrub growth in the low Arctic: The relative importance of experimental warming, enhanced nutrient availability, snow depth and caribou exclusion. Environmental Research Letters 7(3), 034027. https://doi.org/10.1088/1748-9326/7/3/034027

Zamin, T.J., Bret-Harte, M.S., and Grogan, P. 2014. Evergreen shrubs dominate responses to experimental summer warming and fertilization in Canadian mesic low Arctic tundra. Journal of Ecology 102(3):749-766. https://doi.org/10.1111/1365-2745.12237

Zelazny, V.F., Ng, T.T.M., Hayter, M.G., Bowling, C.L., and Bewick, D.A. 1989. Field guide to forest site classification in New Brunswick: Harvey-Harcourt-Fundy site regions. Fredericton: New Brunswick Department of Natural Resources and Energy.

Zhang, Y., Wang, X., Fraser, R., Olthof, I., Chen, W., McLennan, D., Ponomarenko, S., and Wu, W. 2013. Modelling and mapping climate change impacts on permafrost at high spatial resolution for an Arctic region with complex terrain. The Cryosphere 7:1121-1137. https://doi.org/10.5194/tc-7-1121-2013

Zoladeski, C.A., Wickware, G.M., Delorme, R.J., Sims, R.A., and Corns, I.G.W. 1995. Forest ecosystem classification for Manitoba: Field guide. Edmonton, Alberta: Natural Resources Canada, Canadian Forest Service, Northern Forestry Centre. 